\title{
Evaluation of Interfacial Tension in the Liquid Aluminum Alloy-Liquid Slag System
}

\author{
Magdalena Suchora-Kozakiewicz ${ }^{\text {a* }}$, Jacek Jackowski ${ }^{\mathrm{a}}$ \\ aPoznan University of Technology, Institute of Material Technology, Piotrowo 3, 60-965 Poznan, Poland \\ *e-mail: magdalena.suchora@put.poznan.pl
}

Received: 19 November 2016/Accepted: 9 January 2017/Published online: 17 March 2017

This article is published with open access at AGH University of Science and Technology Press

\begin{abstract}
In the present paper, the results from investigations regarding interfacial tensions present at the borders of a liquid aluminum alloy and two selected melted fluxes (mixtures of salts) are presented. The fluxes feature solidification characteristic curves that are very close to each other as well as differentiated chemical compositions. For the comparative investigations, the so-called surface property index (WS) is calculated for both fluxes with the use of the ion theory of slags. The investigations of the interfacial tensions were conducted on a stand that enabled the measurement of the force values accompanying the tearing-off of the probe from the interfacial surface. A very clear relationship between the interfacial tension values and the WS index values that characterize both fluxes was found. An increase in the WS index value resulted in an increase in the investigated interfacial tension values. It was also found that, in both cases under investigation, an increase in the system temperature value resulted in an increase of the values of the interfacial tensions present within. In the conclusion, we state that the metallurgical treatments (for instance, the recycling of the cast metal composite materials by way of component separation) should be conducted with the use of salt mixtures (fluxes) characterized with WS index and melting temperature values as low as possible.
\end{abstract}

\section{Keywords:}

metallurgical systems, interfacial tensions, recycling, fluxes, slags

\section{INTRODUCTION}

In each, in practice, metallurgical process, two differentiated liquid phases occur: melted metal (alloy) and liquid slag. The slags present on the surface of the metal baths originate from the melting of the substances called fluxes, the chemical reaction products, and the physical phenomena accompanying the melting processes. In the processes connected with the metallurgical treatment of aluminum alloys, the fluxes applied are mainly salt mixtures (most often those of chlorides and fluorides). In practice, fluxes of a pre-defined character implied by their application purpose are used; thus, cover, deoxidizing, degasifying, modifying, etc. fluxes are applied $[1,2]$. In the process of recycling the cast composite materials (consisting in the separation of primary components, in particular), the application of the appropriate fluxes called the recycling centers is necessary [3, 4]. The slag-forming fluxes are characterized by a series of properties (in the liquid state) on which the purpose and the scope of their application, effectiveness, and efficiency depend. Among the poorly recognized and very significant features of the fluxes applicable in aluminum alloy metallurgy, there are interfacial tension values occurring at the border that separate them from the liquid metal bath.

\section{INTERFACIAL TENSIONS IN THE ALUMINUM ALLOY METALLURGICAL PROCESSES}

A conclusion implied by wide investigations concerning the effectiveness of the refining treatments for alumina alloys with the use of fluxes of differentiated chemical compositions was a coarse determination of the most-beneficial interfacial tension values in the systems under investigation. In the dependence of the alloys under investigation as well as the slag-forming mixtures (fluxes) applied, the tension values were determined within the limits of $540-740 \mathrm{mN} / \mathrm{m}$ [5]. The analyses connected with the recycling condition for cast composite materials on the metal matrix of aluminum alloys (of suspension or reinforcement saturated types) through separation of the components (the matrix and the reinforcing material) showed that, in the recycling systems, the interfacial tension values at the border of the liquid matrix and the recycling center should be as low as possible [4, 6]. There are some possibilities to determine the interfacial tension values [7], but the specific conditions (temperature, non-transparency, reactivity, and so on), typical for the systems with a share of aluminum alloys, make it so the possibilities are strongly limited. Initial tests with the use of our own construction stand and of the ring method taken for an alloy aluminum and mixtures 
of two salts ( $\mathrm{KCl}$ and $\mathrm{NaCl})$ of differentiated shares made it possible to evaluate the tensions [8]. Differentiated interfacial tension values were found, while the other measuring conditions remained constant. A result of this finding was a development, based on the ion slag theory [9] of the so-called surficial property index (WS) for melted slag-forming mixtures $[7,10]$. Its numerical value depends on the share of individual cations present in the slag (flux) as well as their magnitude and valence. To verify this, it was decided to make a series of experiments with the use of our own measuring stand.

\section{INTERFACIAL TENSION VALUE EVALUATION TRIALS}

The leitmotif of the assumed trials was to determine the interfacial tension values at the border (interface) of the liquid aluminum alloys and two melted salt mixtures (fluxes) of the solidification point values close to each other, but possibly clearly differentiated values of calculated surficial property indices, WS.

For making our investigations, a stand of our own construction [8] was used, composed of the following:

- a resistance, laboratory crucible furnace from the Nabertherm company;

- a framework structure complete with a movable outrigger located over the furnace and within its vertical axis;

- a servo-drive enabling vertical probe movement (within the furnace axis) at an adjustable speed;

- a dynamometer, model FH2, from the Sauter company, with an indication accuracy of $0.001 \mathrm{~N}$;

- a ring-shaped probe $(\phi=60 \mathrm{~mm})$ made of stainless steel wire $(\phi=0,6 \mathrm{~m})$;

- a computer, complete with software for dynamometer reading recording.

The probe was connected with a rigid tie-rod, with the dynamometer and the structure developed made it possible for its slow displacementin the verticaldirection (up - down) at an adjustable speed along an interval covering the interfacial surface under investigation. To ensure a high thermal inertia for the systems under investigation, a massive thick-walled cast iron crucible was applied where the system components were to be melted (fragments of alloy pig and applied salt mixtures) and the trials were to be taken. The inner surface of the crucible was covered with a colloidal graphite suspension.

For taking tests (trials), the aluminum alloy ENAW 1070A (as per PN EN 573-3:1998) was used, with an $\mathrm{Al}$ content of $99.7 \%$ and two salt mixture sets (noted as Flux 1 and Flux 2). The sets were selected from a group of a dozen or so mixtures of differentiated chemical compositions for which the solidification curves had been determined and the WS index values calculated. In Table 1 is shown the chemical compositions of the flux used and the its corresponding values of WS index.
Table 1

The chemical compositions of fluxes

\begin{tabular}{ccccc}
\hline \multirow{2}{*}{ No. flux } & \multicolumn{2}{c}{ Chemical composition wt.\% } & \multirow{2}{*}{ WS index } \\
\cline { 2 - 4 } & $\mathrm{KCl}$ & $\mathrm{NaCl}$ & $\mathrm{NaF}$ & \\
\hline Flux no. 1 & 20 & 62 & 18 & 0.9403 \\
\hline Flux no. 2 & 70 & 13 & 17 & 0.8241 \\
\hline
\end{tabular}

The salt mixtures selected and used featured almost identical and near-eutectic solidification characteristic curves. The solidification temperature range for Flux 1 amounted to $645-641^{\circ} \mathrm{C}$ at the value of the index WS= 0.9403 , and for Flux $2-643-639^{\circ} \mathrm{C}$, at the value of the index WS $=0.8241$. In Figures 1 and 2, the solidification characteristic curves have been presented for both of the selected mixtures of salts (fluxes).

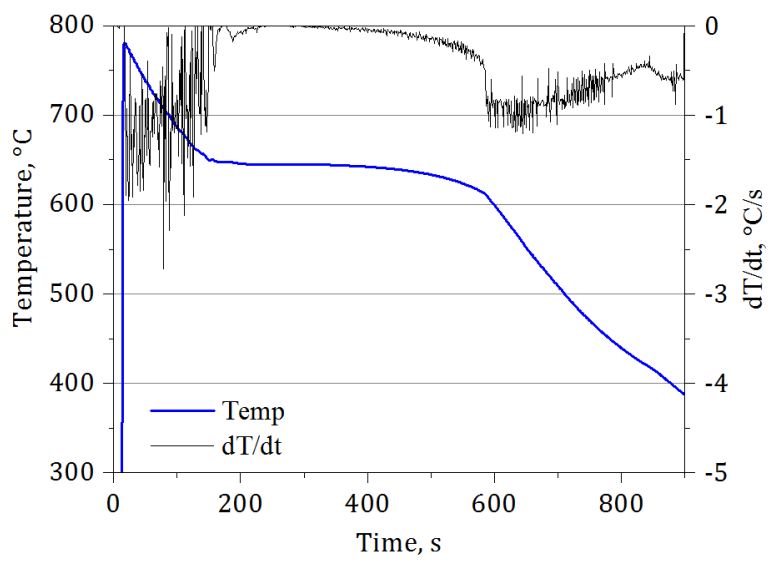

Fig. 1. Solidification characteristic curve for Flux $1(\mathrm{WS}=0.9403)$

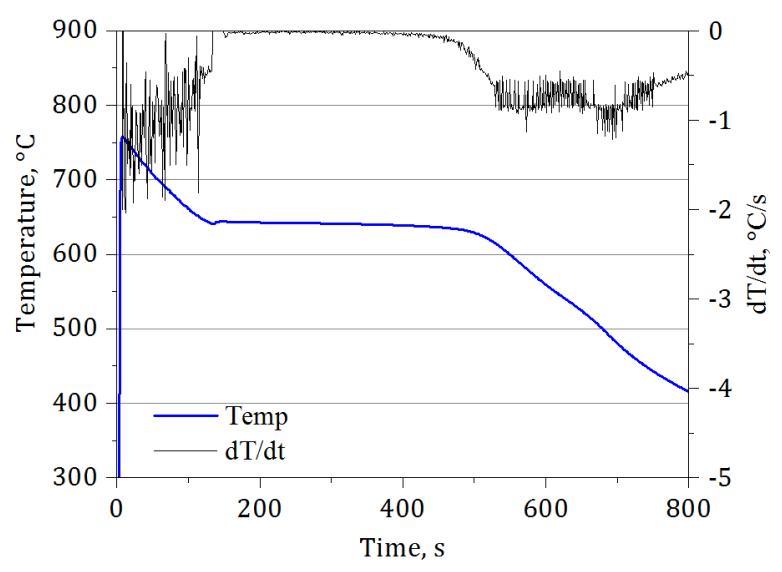

Fig. 2. Solidification characteristic curve for Flux $2(\mathrm{WS}=0.8241)$

Each of the trials consisted in the following:

a) heating the furnace crucible up to a temperature value of ca. $800^{\circ} \mathrm{C}$;

b) loading the charge (alloy + salt mixture), melting it and heating up to the temperature value of $800^{\circ} \mathrm{C}$;

c) preparation of the measuring set;

d) immersion of the probe in liquid alloy (via the flux layer); 
e) resetting the dynamometer indications;

f) slow raising (withdrawal) of the probe from the metal bath at continuous dynamometer reading logging (once per half second);

g) complete displacement of the probe into the liquid flux layer after it is torn from the liquid alloy surface.

After "breaking" the probe contact with the metal bath, the actions d-g were repeated at the uninterrupted observation of the system and cyclic control of its temperature with the use of an immersion-type thermocouple. To avoid possible "electro-motoric" disturbances, the furnace was switched off during the determination period. The trials were finished when the first crystals of the solidifying flux appeared on the system surface. After reheating the system under investigation (and a possible probe substitution), the actions in accordance with the scheme mentioned hereinabove were continued. In Figures 3 and 4, examples of the force values logged by the measuring system are presented. The drops in the force values accompanying "the break" of the probe contact with the interfacial surface: metal - flux (marked in the plots) constituted the basis for calculation of the interfacial tensions.

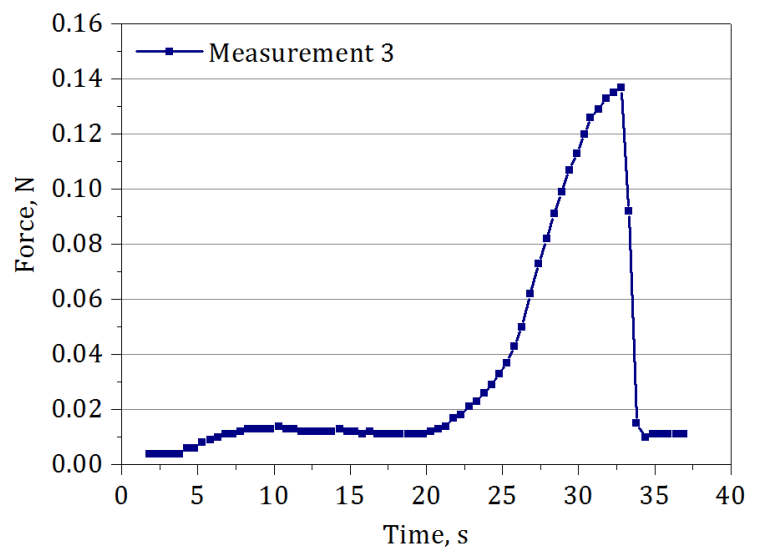

Fig. 3. The plot of force value changes in the system: aluminum alloy flux No. 1

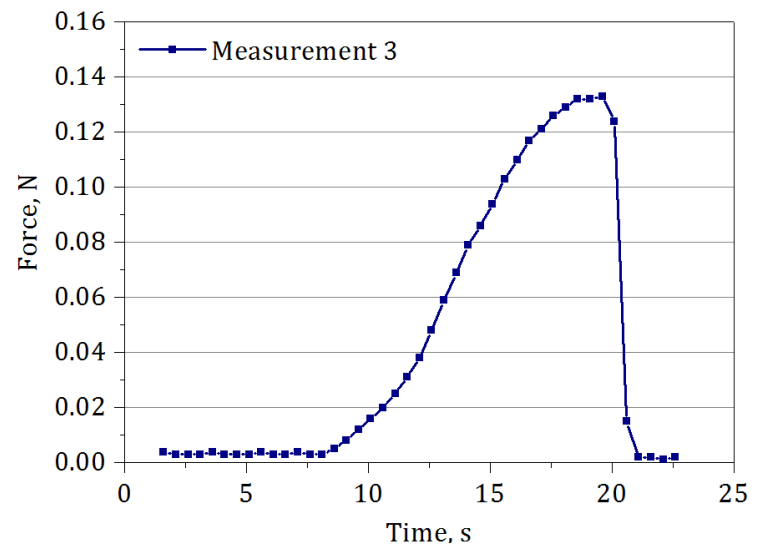

Fig. 4. The plot of force value changes in the system: aluminum alloy flux No. 2
In Table 2, the interfacial tension values measured due to the trials conducted are listed.

Table 2

Interfacial tension values measured at the border (interface) of the liquid aluminum alloy and fluxes under investigations

\begin{tabular}{ccc}
\hline \multirow{2}{*}{ Temperature, ${ }^{\circ} \mathrm{C}$} & \multicolumn{2}{c}{ Interfacial tension value, $\mathrm{mN} / \mathrm{m}$} \\
\cline { 2 - 3 } & Flux No. 1 & Flux No. 2 \\
\hline 800 & 405,397 & 347 \\
\hline 795 & - & 345 \\
\hline 790 & 392 & $345,342,337,339$ \\
\hline 785 & - & 39,337 \\
\hline 780 & $400,403,389$ & 332 \\
\hline 770 & 382,379 & 326,311 \\
\hline 765 & 374 & 329,313 \\
\hline 760 & 382,403 & 318 \\
\hline 755 & 357,389 & 310 \\
\hline 750 & 368 & 308,305 \\
\hline 745 & 350,361 & 300 \\
\hline 740 & - & 297,297 \\
\hline 730 & 382,376 & - \\
\hline 725 & 374 & - \\
\hline 720 & 339,376 & - \\
\hline 700 & 337,332 & 284,284 \\
\hline
\end{tabular}

A graphical image of the Table 2 contents are the plots presented in Figure 5.

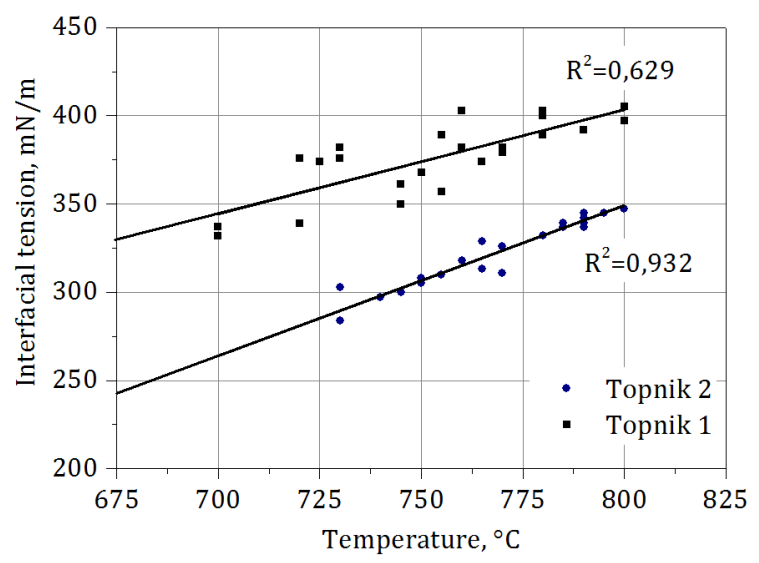

Fig. 5. Interfacial tension values determined at the border interface) of the liquid aluminum alloy and fluxes under investigation.

The equations describing both straight lines were created on the basis of both experimental data sets, and the left-hand ends extend outside the interfacial tension measured values, creating "the trend line."

\section{DISCUSSION OF THE TAKEN INVESTIGATION COURSE AND THE RESULTS OBTAINED}

The course of the investigations taken and the results obtained should be recognized as satisfactory. The method chosen as well as the measurement taking way proved to be effective, providing credible results. Into the basic 
difficulties, it should be included the limited possibilities of execution of the trials at temperature values of ca. $700^{\circ} \mathrm{C}$ and lower. In spite of this, the temperature value of the systems under investigation ensured the decided liquidity of both phases (metal - flux), adequate possibilities of the tension evaluation at their border (interface) were hindered or even impossible due to creation of salt crystals at the border (interface) of the liquid flux and atmosphere. No additional thermo-insulating shields were applied in order to not hinder the observation of the systems under investigation and the fact of the appearance of crystals on the frame fixing the probe (for example) disqualified the force measurement result logged values from further calculations.

Another difficulty produced the limited life of the probes applied due to the physical - chemical aggressiveness of the environment wherein they worked. This resulted in their need to be replaced frequently, which, in turn, forced the absolute standardization of their geometrical dimensions and the possibility of fast replacement.

The results obtained proved the undisputed relationship between the interfacial tension values at the border (interface) of the liquid phases of the systems of the chemical composition of the salt mixtures serving for the production of fluxes and, therefore, the values of the defined surficial property indices, WS. An increase in the WS index value determined for the relevant flux (Flux $1-$ WS $=0.9403$, Flux $2-$ WS $=0.8241$ ) results in an increase of interfacial tensions at its border (interface) with the liquid metal phase. This means that the increase of $\mathrm{NaCl}$ results in a decrease of the WS index when compared to $\mathrm{KCl}$, and this results in the lower values of interfacial tension at the interface's liquid metal - liquid flux. A characteristic thing is the interfacial tension value increase in the systems under investigation, together with their temperature increase as well as the near parallelism of the lines describing the relationship for both fluxes.

The interfacial tension values found at the border (interface): liquid aluminum alloy - liquid flux, are - in both systems under investigation, half of the values evaluated by other authors $[5,11]$.

\section{CONCLUSIONS}

The solidification characteristic curves worked out for the slag-forming mixture group made it possible to select two salt mixture sets (Flux 1, Flux 2). Both fluxes were characterized by very close solidification temperature ranges and differentiated by the chemical composition and WS index values. The experiments taken confirmed the existence of a relationship between interfacial tension values, chemical composition, and WS index values. An increase in the WS index value (dependent on the salt mixture composition) for the relevant flux results in an increase in the interfacial tension values at the border (interface) with liquid metal. In addition, a clear increase was found in the interfacial tension values accompanying the metallurgical system temperature increase. This fact suggests the reasonability of the recycling treatments for cast composite (metal) materials consisting in the separation of components and refining the aluminum alloys with respect to the solid inclusions present therein at a temperature value as low as possible. This means that, when composing the chemical compositions of salt mixtures intended for aluminum alloy metallurgy, one should be guided by the aim that the mixtures featured with WS index values as low as possible and also with low melting point values. Since most of the companies' slag-forming mixtures have chemical compositions impossible to be determined (patent protection), the basis for the selection should be their melting point (as low as possible).

\section{REFERENCES}

[1] Goederitz A.H.F. (1955). Metallguss: Entwicklung der deutschen Metallgusstechnik II Teil, Schmelzen und Legieren. Haale (Saale): VEB Wilhelm Knapp Verlag.

[2] Górny Z., Lech Z., Rutkowski K., Strojny Z. \& Welkens T. (1963). Odlewnicze stopy metali nieżelaznych. Technologia topienia and odlewania. Warszawa: WNT.

[3] Jackowski J. (2006). Rola napięć międzyfazowych w recyklingu metalowych tworzyw kompozytowych $\mathrm{z}$ nasycanym zbrojeniem. Archiwum Technologii Maszyn i Automatyzacji, 26(1), 39-46.

[4] Szymański P. (2009). Recykling odlewów z metalowych kompozytów zawiesinowych. Doctoral thesis. WBMiZ, Politechnika Poznańska, Poznań, Poland.

[5] Postołek H. \& Adamski C. (1981). Wpływ napięć międzyfazowych na rafinujące oddziaływanie żużli. Archiwum Hutnictwa, 26(4), 557-579.

[6] Jackowski J., Nagolska D., Szymański P. \& Szweycer M. (2008). Analiza warunków recyklingu odlewów i odpadów kompozytowych. In Sobczak J. (Ed.): Innowacje w odlewnictwie - cz. II, Kraków: Instytut Odlewnictwa, 303-308.

[7] Jackowski J., Suchora-Kozakiewicz M. \& Szymański P. (2014). Ocena napięć międzyfazowych w ciekłych układach metalurgicznych. In ŚwiątkowskiK. (Ed.): Polska metalurgia $w$ latach 2011-2014. Kraków: Wydawnictwo Komitetu Metalurgii PAN, 373-387.

[8] Jackowski J. \& Suchora-Kozakiewicz M. (2011). Stanowisko do oceny napięć międzyfazowych w ciekłych recyklingowych układach metalurgicznych. Archiwum Technologii Maszyn i Automatyzacji, 31(3), 9-19.

[9] Mazanek T. \& Mamro K. (1968). Metalurgia żelaza. Katowice: Wydawnictwo Śląsk.

[10] Jackowski J. \& Suchora-Kozakiewicz M. (2015). Assessment of usability of molten salt mixtures in metallurgy of aluminum alloys and recycling of composite materials based on the matrix of Al alloys. Archives of Metallurgy and Materials, 60(3), 1731-1735.

[11] Adamski C., Postołek H., Kucharski M. \& Rzadkosz S. (1979). Nowe żużle pokrywająco-rafinujące dla aluminium i jego stopów. Przegląd Odlewnictwa, 79(12), 351-355. 